\title{
MENGKAJI MAKNA KEDEKATAN DAN KEBERSAMAAN ALLAH DENGAN MAKHLUK-NYA DALAM TAFSĪR AL-MISHBĀH
}

\author{
Basrian \\ Universitas Islam Negeri Antasari Banjarmasin \\ Basrian@uin-antasari.ac.id
}

Diterima 10 April 2021 | Direview 20 Mei 2021 | Diterbitkan 25 Juni 2021

\begin{abstract}
Knowing Allah and uniting Him is a concept of monotheism which is called for by the Qur'an and conveyed by the Prophet Mubammad. to bis people. Thus it is an obligation for Muslims to study it seriously and deeply. Among the teachings of this monotheism are the verses that inform that Allah is close to His creatures, even Allab Himself is with His creatures wherever they are. These verses and their meanings can cause some Muslims to misunderstand them. Because, the verses seem to state that God is in the heart or God is united or together with His creatures, even God is everywhere. Information on the verse of the Qur'an that mentions Allah is near or Allah is with His servants, of course it cannot be understood simply that Allah is close as close to one thing as another. Or God is one with man as understood by some Sufis. If this is the case, it is clearly contrary to the principles of monotheism taught by the holy Qur'an. To find out what the meaning of the closeness and togetherness of Allah is, this paper tries to trace the answer through M. Quraish Shihab's Tafsir al-Mishbäh.
\end{abstract}

Keywords: Close, Together, Piety, Knowledge, Help, Support.

\section{Abstrak}

Mengenal Allah dan mengesakan-Nya merupakan konsep ajaran taubid yang diserukan oleh Alquran dan disampaikan oleh Rasulullah saw. kepada umatnya. Dengan demikian merupakan kewajiban bagi umat Islam mempelajarinya secara serius dan mendalam. Di antara ajaran taubid ini ialah adanya ayat-ayat yang menginformasikan bahwa Allab itu dekat dengan makblukNya, bahkan Allah sendiri bersama dengan makbluk-Nya di manapun mereka berada. Ayat-ayat tersebut dan yang semakna dengannya bisa menyebabkan sebagian kaum muslim keliru memabaminya. Sebab, ayat-ayat itu terkesan menyatakan bahwa Allah ada di hati atau Allah menyatu atau bersama dengan makbluk-Nya, babkan Allah ada di mana-mana. Informasi ayat Al-Qur'an yang menyebut Allab itu dekat atau. Allab bersama bamba-Nya, tentu tidak dapat dipabami begitu saja bahwa Allah itu dekat sebagaimana dekatnya antara sesuatu dengan yang lain. Atau Allab menyatu dengan diri manusia sebagaimana dipahami oleh sementara kaum sufi. Jika demikian halnya, jelas bertentangan dengan prinsi-prinsip taubid yang diajarkan oleh kitab suci Alquran Untuk mengetahui bagaimana makna kedekatan dan kebersamaan Allah ini, tulisan ini mencoba menelusuri jawabannya melalui Tafsìr al-Mishbäh karya M. Quraish Shiba.

Kata Kunci: Dekat, Bersama, Takwa, Imu, Bantuan, Dukungan.

\section{Pendahuluan}

Kitab suci Alquran menjadi pedoman hidup bagi umat Islam dalam melaksanakan ajaran agama yang diyakininya. Untuk menjadikan Alquran sebagai pedoman hidup diperlukan pemahaman yang benar. Memahami Alquran dengan benar tentu tidak mudah karena memerlukan perangkat ilmu yang mendukung, seperti Ilmu Tafsìr, Ilmu Tata Bahasa Arab, Ilmu Balāgah, Ilmu Asbāb an-Nuzūl dan lain-lain. Tanpa ilmu pendukung itu, ayat-ayat Alquran tidak bisa dipahami secara baik dan benar.

Jika dicermati, Alquran banyak memuat pokok ajaran Islam yang sangat penting bagi umat manusia. Di antaranya yang paling mendasar adalah masalah keimanan atau tauhid, disamping juga masalah ibadah, akhlak, dan lain-lain. Pada aspek ajaran tauhid atau akidah ini merupakan ajaran pokok yang dibawa oleh Alquran, yaitu ajaran tentang pengakuan terhadap keesaan Allah secara murni. bahkan ajaran tauhid merupakan dasar dari segala akar ajaran Islam. Mengenal Allah dan mengesakan-Nya merupakan konsep ajaran tauhid yang dibawa oleh Nabi dan Rasul Allah secara berkesinambungan hingga sampai kepada umat Islam saat ini. Dalam perkembanganya, pemahaman terhadap ajaran tauhid ini memunculkan berbagai Aliran Kalam/Tauhid seperti Asy'ariyah, Mu'tazilah, Jabariyah, Qadariyah, Khawarij, Syi'ah dan lain-lain.

Di tengah masyarakat muncul pula paham ajaran mengenal asal kejadian diri" "ilmu sabuku" atau "tasawuf sir" dan sebagainya. Ajaran-ajaran seperti ini tidak bisa dibiarkan, sebab

${ }^{1}$ Lihat hasil penelitian Asmaran dkk., dengan judul

${ }^{2}$ Lihat Ahmad,Pengajian Tasawuf Sirr di Kalimantan Selatan, (Banjarmasin, Antasari Press, 2014). 
dapat merusak akidah umat Islam. Karena itu umat Islam wajib menggali dasar-dasar ajaran tauhid ini dengan merujuk kepada kitab petunjuk yaitu Alquran al-Karīm dan Sunnah Rasul, agar mereka terhindar dari kekeliruan dan bahkan terbebas dari kesyirikan.

Selain persoalan di atas, ditemukan petunjuk Alquran terkait dengan ajaran tauhid ini ialah adanya ayat-ayat yang menginformasikan bahwa Allah itu dekat dengan makhluk-Nya, bahkan Allah sendiri bersama dengan makhluk-Nya di manapun mereka berada. Ayat-ayat tersebut dan yang semakna dengannya bisa menyebabkan sebagian kaum muslim keliru memahaminya. Sebab, ayat-ayat itu terkesan menyatakan bahwa Allah ada di hati atau Allah menyatu atau bersama dengan makhluk-Nya, bahkan Allah ada di mana-mana. Diantaranya Surah Qaf: 16, al-Hadid: 4, az-Zukhruf: 84 dan lain-lain.

Pemahaman yang tidak benar akan membawa kepada kesesatan dan merusak akidah serta tidak sesuai dengan prinsip tauhid yang dibawa oleh para Nabi dan Rasul Allah. Oleh karena itu bagaimana sebenarnya makna kedekatan dan kebersamaan Allah dengan makhlukNya ini, serta media atau sarana apa yang bisa mengantarkan seseorang dekat dan bersama dengan Allah merupakan pertanyaan-pertanyaan yang menghendaki jawaban yang jelas agar petunjuk Alquran itu dapat dipahami dengan sebaik-baiknya dan umat Islam terbebas dari kekeliruan dalam memperkuat akidah atau keyakinannya.

Memahami dan menggali makna ayat Alquran bukan pekerjaan yang mudah. Untuk itu diperlukan tafsir, karena tafsir secara bahasa berarti menjelaskan dan menerangkan (al-idhah wa at-tabyin). Dalam tulisan ini penulis fokuskan pada kitab Tafsir al-Mishbäh karya M. Quraish Shihab. Pemilihan tafsir ini dikarenakan penulisnya adalah seorang ulama dan pakar di bidang tafsir yang dikenal luas oleh masyarakat Indonesia. Selain itu, uraian dan penjelasan beliau mudah diserap karena pemikirannya sesuai dengan budaya bangsa Indonesia.

Selanjutnya pertanyaan yang muncul adalah bagaimana makna kedekatan dan kebersamaan Allah dengan hamba-Nya dalam Tafsir al-Mishbäh. Rumusan masalah ini selanjutnya dijabarkan lagi: 1 . Ayat-ayat apa saja yang terkait dengan makna kedekatan Allah dengan hamba-Nya. 2. Ayat-ayat apa saja yang terkait dengan makna kebersamaan Allah dengan hamba-Nya. 3. Bagaimana penjelasan tafsiran penulis Tafür al-Mishbäh terkait kedua hal tersebut. 4. Apa sarana atau media yang dapat mengantarkan seseorang dekat dan bersama Allah.

\section{Sekilas Tentang Tafsīr al-Misbāh dan Penulisnya}

Nama yang tertera sebagai penulis Tafsìr al-Mishbāh adalah M. Quraish Shihab atau lengkapnya Muhammad Quraish Shihab, ia tidak asing lagi bagi masyarakat Indonesia khususnya kalangan akademisi, karena berbagai karya tulisnya yang terpublikasi luas dan tersebar di berbagai perpustakaan perguruan tinggi banyak dibaca dan dijadikan sumber rujukan dalam karya tulis atau penelitian mereka.

Ia dilahirkan di Rappang, Sulawesi Selatan, pada tanggal 16 Februari 1944. Ia mendapatkan pendidikan dasarnya di Ujung Pandang, kemudian melanjutkan pendidikan menengahnya di Malang, sambil "nyantri” di Pondok Pesantren Dārul Hadīts al-Fāqihiyyah. Pada tahun 1958, ia berangkat ke Kairo, Mesir dan diterima di kelas II Tsanawiyyah al-Azhar. Pada tahun 1967, ia meraih gelar Lc. (S-1) di Fakultas Ushuluddin Jurusan Tafsir dan Hadits Universitas al-Azhar. Kemudian ia melanjutkan pendidikannya di fakultas yang sama, dan pada tahun 1969 meraih gelar M.A. untuk spesialisasi bidang Tafsir Alquran dengan judul tesis al-I'jaz, at-Tasyri'ȳy li Alqurān al-Karim. ${ }^{3}$

Pada tahun 1980, Quraish Shihab kembali ke Kairo dan melanjutkan pendidikannya di Universitas al-Azhar. Dua tahun berikutnya(1982), ia menempuh ujian promosi doctor dengan disertasi berjudul "Naz̧ham ad-Durar li al-Biqä’iy, Tahqiq wa Diräsab”. Ia berhasil meraih gelar Doktor dalam ilmu-ilmu Alquran dengan yudisium Summa Cum Laude disertai dengan penghargaan tingkat I, (mumtaz. ma'a martabat al-syaraf al-Üla). ${ }^{4}$ 
Beberapa hal pengabdiannya antara lain sebagai Wakil Rektor Bidang Akademik dan Kemahasiswaan di IAIN Alauddin Ujung Pandang. Selain itu, ia juga diserahi jabatan lain sebagai Koordinator Perguruan Tinggi Swasta (wilayah VII Indonesia Bagian Timur) dan membantu Pimpinan Kepolisian Indonesia Bagian Timur dalam rangka pembinaan Mental. Sejak tahun 1984 Quraish Shihab ditugaskan di Fakultas Ushuluddin dan Fakultas Pacasarjana IAIN Syarif Hidayatullah (sekarang UIN Syarif Hidayatullah) Jakarta. ${ }^{5}$ Menjadi Rektor IAIN Syarif Hidayatullah Jakarta pada tahun 1992-1998. Ia pernah menjabat Ketua Majelis Ulama Indonesia (Pusat), 1995-1998, anggota MPR RI 1982-1987 dan 1987-2002. Pada tahun 1998 dipercaya menjadi Menteri Agama RI. ${ }^{6}$ Aktivitas utamanya sekarang adalah dosen (Guru Besar) Pascasarjana Universitas Islam Negeri (UIN) Jakarta dan Direktur Pusat Studi AlQuran (PSQ) Jakarta. ${ }^{7}$

Karya tulis Quraish Shihab cukup banyak, salah saatunya adalah Tafsir al-Mishbāh yang menjadi sumber pokok dalam tulisan ini. Secara pisik, Tafsir al-Mishbāh yang ada pada penulis ini berukuran $16 \times 24 \mathrm{~cm}$ dengan tulisan hitam di atas kertas putih terdiri atas 15 jilid. Kitab ini diterbitkan oleh Penerbit Lentera Hati Jakarta, Muharram 1434 H./ Nopember 2012 M. edisi baru dan sudah mengalami cetak ulang yang ke-5. Atas dasar data ini menunjukkan bahwa Tafsir al-Mishbāh banyak diminati dan dibaca oleh masyarakat luas. Hal ini terbukti telah mengalami cetak ulang ke-5 sejak edisi baru 2009 hingga tahun 2012. Jika diamati, tafsir ini ditulis cukup tebal bahkan rata-rata setiap jilidnya mencapai antara 600-700-an halaman lebih.

\section{Seputar Pengertian Kedekatan dan Kebersamaan Allah}

Istilah kedekatan berasal dari akar kata "dekat" dengan tambahan awalan ke dan akhiran an yang memiliki beberapa arti: pendek, tidak jauh (jarak atau antaranya), hampir, berhampiran (dengan), akrab; rapat (tt hubungan persahabatan, persaudaraan, dsb), menjelang. ${ }^{8}$ Kedekatan: perihal dekat: contoh saat berekreasi bersama si kecil, Anda dapat memanfaatkannya untuk membina. ${ }^{9}$ Dari beberapa pengertian di atas tampaknya arti yang terakhir yang dimaksudkan di sini yakni "kedekatan" yang diartikan sebagai perihal dekat atau suatu gambaran dekatnya sesuatu dengan yang lain. Ungkapan atau istilah semacam ini sering dipergunakan dalam bahasa pergaulan sehari-hari di masyarakat.

Dalam Kamus Arab Indonesia disebutkan kata "dekat" sebagai arti dari kata Arab: = dekat darinya. Kemudian dari turunan kata ini terdapat berbagai kata lainnya seperti قريب تربابـ (yang dekat, dalam bentuk mubālagah = sangat dekat), أقرب (lebih dekat), تقرب إلى (mendekatkan diri kepada) dan lain-lain.

Adapun kata kebersamaan terdiri dari ke-ber-sama-an dari akar kata "sama" yang berarti : 1. Serupa (halnya, keadaannya dsb), tidak berbeda, tidak berlainan, 2. Berbarengan, bertepatan, 3. Sepadan, seimbang, sebanding, setara. Sedangkan kata kebersamaan mengandung arti hal bersama, ${ }^{12}$ namun dalam kata-kata bijak kata "Kebersamaan" memiliki makna sebuah ikatan yang terbentuk karena rasa kekeluargaan/persaudaraan, lebih dari sekedar bekerja sama atau hubungan profesional biasa. Kebersamaan memiliki empat unsur yang harus diciptakan

${ }^{5}$ Ibid, vi.

${ }^{6}$ M. Quraish Shihab, Lentera Al-Quran Kisah dan Hikmab Kehidupan, (Bandung: Penerbit Mizan, 2013), 5.

${ }^{7}$ M. Quraish Shihab, Secercah Cahaya IlahiHidup Bersama Al-Quran, (Bandung: Penerbit Mizan, 2007), cet.

II, 6 .

${ }^{8}$ Tim Penyusun Kamus Pusat Pembinaan dan Pengembangan Bahasa, Kamus Besar Bahasa Indonesia, (Jakarta: Balai Pustaka, 1990), cet. Ke-3, 456

${ }^{9}$ Ibid

${ }^{10}$ Ahmad Warson Munawwir, al-Munawnir Kamus Arab Indonesia, (Surabaya: Pusaka Progressif, 1997), 1102.

${ }^{11} \mathrm{Ibrahim}$ Anis dkk, al-Mu'jam al-Wasith, (Kairo: Majma' al-Lugah al-'Arabiyyah, tt.), 757.

${ }^{12} \mathrm{KKB}$, Ibid, 774. 
dan dijaga oleh setiap individu yang tergabung di dalamnya, yaitu: sehati dan sepikir (satu visi), tidak egois, kerendahan hati, dan kerelaan berkorban. ${ }^{13}$

Pengertian kedekatan dan kebersamaan di atas, lebih menekankan pada aspek kebahasaan dan pengertian yang lazim dalam bahasa komunikasi pergaulan di masyarakat. Para ulama memahami pengertian ini-ketika digandengakan dengan Allah-secara proporsional sesuai dengan sifat-sifat kemuliaan dan keagungan Allah.

\section{Makna Dekat Dengan Allah}

Ada beberapa ayatAlquran yang berbicara tentang kedekatan Allah ini, diantaranya : AlBaqarah [2]: 186, Hūd [11]: 61, Sabā [34]: 50, Qāf [50]:16 dan al-Wāqi’ah [56] : 85.

a. Al-Baqarah [2]: 186.

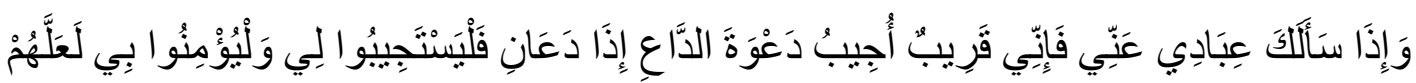

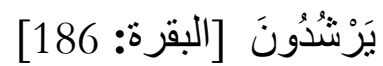

Dalam penjelasannya, Quraish Shihab tidak menegaskan pengertian dekatnya Allah dengan manusia, tetapi ia menyebutkan bahwa "pengetahuan tentang wujud Allah melekat pada fitrah manusia, bukti-bukti wujud dan keesaan-Nya pun terbentang luas". Ungkapan ini agaknya mengingatkan kita kepada seseorang yang sedang kasmaran terhadap kekasihnya dengan pribahasa "jauh di mata dekat di hati". Ini mengandung makna, meski kekasihnya itu berada di suatu tempat yang jauh, tetapi karena rasa cintanya sangat dalam, sehingga ia merasakan bahwa kekasihnya itu ada sangat dekat dalam hati, pikiran dan perasaan. Demikian juga secara fitri manusia itu berasal dari Allah, ${ }^{14}$ sehingga dengan sendirinya manusia merasakan adanya Allah itu dekat dalam pengalaman kehidupannya, ia pun berupaya mencari, menyintai Allah dengan berbagai cara sesuai perasaan naluri beragamanya dan akhirnya ia kembali kepda Allah.

b. Hūd [11]: 61.

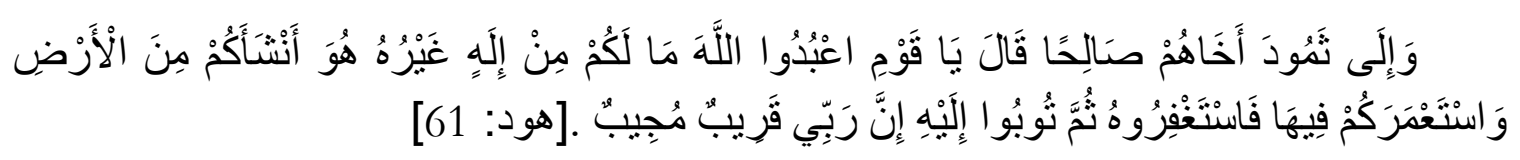

Ayat ini berisi pesan Nabi Shaleh kepada umatnya agar mereka menyembah (beribadah) kepada Allah, memakmurkan bumi ini secara baik dan mohon ampun kepada-Nya atas kelalaian atau kesalahan yang mereka perbuat. Berdasarkan penjelasan di atas, tampaknya bagi Quraish Shihab pemaknaan terhadap ungkapan kalimat إِنَّ رَبِّي قَرِيبَ (sesungguhnya Tuhanku amat dekat) dimaknai dengan kedekatan rahmat-Nya bagi hamba-hamba-Nya, sehingga tidak harus pergi jauh untuk memperoleh rahmat Allah itu. Dengan menyatakan bahwa Allah itu قَرِيبُ -seperti dilukiskan dalam ayat—mengisyaratkan tidak perlu seorang hamba berteriak keras ketika berdo'a. Untuk memperkuat pendapatnya ini, Quraish Shihab merujuk kepada firman Allah surah al-A'rāf 55 dan 205: ${ }^{15}$

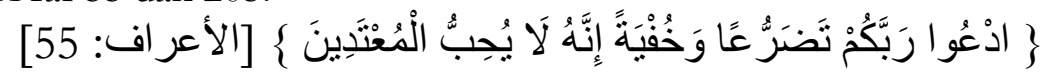

Berdo'alah kepada Tuhanmu dengan berendah diri dan suara yang lembut. Sesungguhnya Allah tidak menyukai orang-orang yang melampaui batas. (Maksudnya: melampaui batas tentang yang diminta dan cara meminta. $)^{16}$

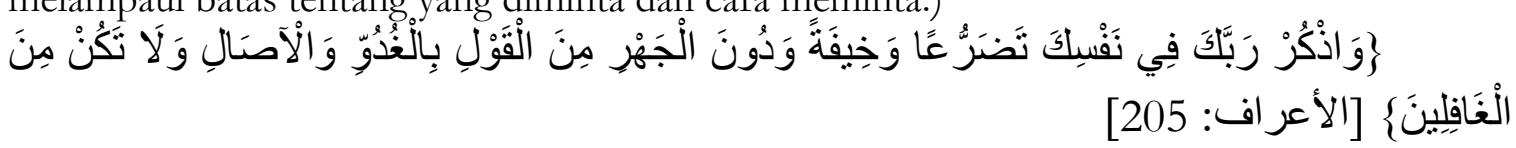

Dan sebutlah (nama) Tuhanmu dalam hatimu dengan merendahkan diri

\footnotetext{
${ }^{13}$ http:/ / kasminarif.blogspot.co.id, diakses tanggal 20 November 2017.

${ }^{14}$ Lihat QS. al-Hijr [15]: 29, as-Sajadah [32]: 9 dan Shād [38]: 72.

${ }^{15}$ Ibid, 668.

${ }^{16}$ Tim Penerjemah Departemen Agama, op.cit,. 230.
} 
dan rasa takut, dan dengan tidak mengeraskan suara, di waktu pagi dan petang, dan janganlah kamu termasuk orang-orang yang lalai. ${ }^{17}$

Selanjutnya berkaitan dengan kata مُجِيْب (Yang memperkenankan, mengabulkan do'a hamba-Nya), Quraish Shihab menjelaskan kata tersebut terambil dari kata أجاب (ajāba). Dari akar kata yang sama lahir kata jawāb, yakni jawaban. Kata Mujīb adalah pelaku jawaban itu/yang menjawab. Sementara ulama berpendapat bahwa kata ini pada mulanya berarti memotong seakan-akan yang memperkenankan permohonan, memotong permohonan dan menghentikannya dengan jalan mengabulkan, demikian juga yang menjawab pertanyaan,memotong pertanyaan dengan jawabannya. Kata ini hanya ditemukan sekali dalam Alquran yaitu pada ayat ini, dan sekali juga dalam bentuk jamak mujībūn (surah ash-Shaffāt: 75). ${ }^{18}$

Dengan mengutip pendapat Imam al-Gazali, Quraish Shihab menjelaskan Allah Mujizb, adalah Ia yang menyambut permintaan para peminta dengan memberinya bantuan, do'a yang berdo'a dengan mengabulkannya, permohonan yang terpaksa dengan kecukupan bahkan memberi sebelum dimintai dan melimpahkan anugerah sebelum dimohonkan. Ini hanya dapat dilakukan oleh Allah karena hanya Dia yang mengetahui kebutuhan dan hajat setiap makhluk sebelum permohonan mereka. ${ }^{19}$

c. Sabā [34]:50:

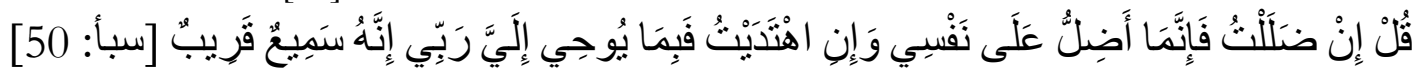

Dalam ayat ini, Allah memerintahkan Nabi Muhammad saw., bahwa: Katakanlah kepada para pembangkang itu: "Jika seandainya aku telah sesat dan menyalahi kebenaran, maka sesungguhnya aku sesat atas kemudharatan diriku sendiri, yakni aku sendiri yang menanggung kerugiannya; dan jika aku mendapat petunjuk, maka petunjuk itu adalah disebabkan oleh karunia Allah melalui apa yang diwahyukan Tuhanku kepadaku. Sesungguhnya Dia Maha Mendengar lagi Maha Dekat dengan pengetahuan dan pertolongan. ${ }^{20}$

Selanjutnya Quraish Shihab menjelaskan سَيعِ قَرِيب (Dia Maha Mendengar lagi Maha Dekat) dapat dipahami sebagai ancaman bagi para pembangkang, sekaligus janji pertolongan dan dukungan kepada yang taat. Dengan merujuk kepada pendapat Thabāthabā'I, kalimat yang menutup ayat di atas menunjukkan bahwa Allah mendengar ajakan dakwah. Jarak yang jauh tidak menjadi penghalang bagi-Nya. ${ }^{21}$ Ketika menafsirkan ayat berikutnya yakni ayat 51 dari surah Sabā ini, kata qarīb disebutkan bahwa Allah telah menyipati diri-Nya dengan qarīb (Maha Dekat) seperti juga dalam firman-Nya pada surah al-Wāqi'ah [56]: 85, Qāf [50]: 16. ${ }^{22}$

Berdasarkan uraian ayat di atas, dapat dipahami bahwa Maha Dekat Allah dalam penghujung ayat ini tidak dipahami dekat secara harfiah, tetapi dimaknai dengan kedekatan pemberian janji pertolongan dan bantuan-Nya kepada hamba-hamba-Nya yang taat (patuh). Kata Qarīb (Maha Dekat) itu sendiri merupakan sifat yang Allah sendiri menyebut diri-Nya sebagai atribut Dzat Yang Maha Sempurna.

d. Qāf [50]:16:

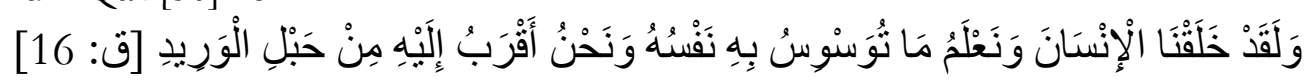

Dalam Tafsìr al-Mishbāh dijelaskan firman Allah: Dan sesungguhnya Aku bersumpah bahwa Kami, yakni Allah, dengan kuasa-Nya bersama ibu bapak yang dijadikan-Nya sebagai perantara telah menciptakan manusia serta memelihara sampai waktu yang ditentukan baginya,

\footnotetext{
${ }^{17}$ Ibid, 256.

${ }^{18}$ M. Quraish Shihab, Tafsìr al-Mishbäh Vol. V, Loc.cit.

${ }^{19} \mathrm{Ibid}$.

${ }^{20}$ M. Quraish Shihab, Tafsìr al-Mishbāh Vol. X, Op.cit, 649.

${ }^{21}$ Ibid.

${ }^{22}$ Ibid, 652.
} 
dan Kami, yakni Allah serta malaikat-malaikat yang ditugaskan mendampingi manusia, senantiasa mengetahui dari saat ke saat apa yang dibisikkan oleh hatinya, dan Kami bersama malaikat-malaikat-dengan pengetahuan Kami itu-lebih dekat kepadnya daripada urat lehernya sendiri kendati setiap manusia amat dekat kepada urat leher masing-masing. ${ }^{23}$

Selanjutnya kata نُوَسنوِسُ biasanya digunakan untuk bisikan-bisikan negatif. Ini dapat dilakukan oleh nafsu manusia dan juga setan. Yang paling rahasia pada diri manusia adalah bisikan-bisikan hatinya itu. Allah senantiasa mengetahui bisikan-bisikan hati manusia yang senatiasa terlintas dalam diri manusia, sebagaimana dipahami dari penggunaan bentuk kata kerja masa kini dan masa datang. ${ }^{24}$

Kata الَْرِِيد ada yang memahaminya dalam arti urat leher, ada juga yang mengartikannya urat-urat yang tersebar di tubuh manusia tempat darah mengalir. Dengan merujuk pendapat Ibn 'Āsyūr mengartikannya sebagai pembuluh darah di jantung manusia. Bagaimana pun, kata tersebut bermaksud menggambarkan sesuatu yang menyatu dalam diri manusia. Bahkan menurut Ibn 'Āsyūr, pembuluh darah itu kendati sangat dekat-karena ketersembunyiannya - maka manusia tidak merasakan kehadirannya dalam dirinya. Demikian juga dengan kedekatan dan kehadiran Allah melalui pengetahuan-Nya, manusia tidak merasakannya. ${ }^{25}$

Menurut Quraish Shihab, firman Allah وَنَحْنُ أَفْرَبُ إِلَنْهِ مِنْ حَبْلِ الََْرِيد merupakan suatu kiasan betapa Allah Maha Mengetahui keadaan manusia yang paling tersembunyi sekalipun. Kalimat itulah yang paling mudah dimengerti walau pada hakikatnya ilmu Allah melebihi apa yang dilukiskan itu. Untuk memperkuat argumentasi ini, Quraish Shihab merujuk QS. Thāhā [20]; 7:

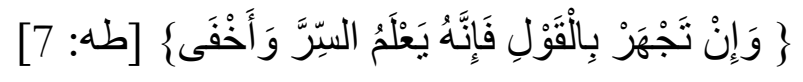

Dalam ayat di atas dinyatakan bahwa Allah mengetahui yang nyata, yang rahasia dan yang lebih rahasia dari rahasia. Yang rahasia antara lain adalah bisikan hatinya, sedang yang melebihi rahasia adalah yang melebihi bisikan hati, yakni hal-hal yang telah terpendam di bawah sadar manusia yang telah dilupakan oleh yang bersangkutan. ${ }^{26}$

Kiasan yang diberikan ayat di atas-menurut Quraish Shihab-tidak dapat dipahami bahwa Allah menyatu dengan diri manusia, sebagaimana dipahami oleh sementara kaum sufi. Karena kedekatan yang dimaksud adalah kedekatan ilmu-Nya atau seperti pendapatnnya Ibn Katsir, yang dekat adalah malaikat-Nya, kata Kami di sini menurutnya bermakna malaikatmalaikat Kami. Selain itu, ada juga yang memahami, makna kedekatan itu dalam arti kuasa Allah. Yakni kalau urat nadi atau pembuluh darah manusia yang menyalurkan darah dari jantungnya merupakan sesuatu yang sangat besar peranannya dalam hidup manusia, maka kuasa Allah jauh lebih besar dari itu. ${ }^{27}$

Dengan penjelasan di atas, dapat diketahui bahwa Allah "lebih dekat kepadanya dari urat leher" dimaknai dengan: kedekatan Allah melalui pengetahuan-Nya (ilmu-Nya), yang dekat itu bermakna malaikat-malaikat Kami, makna kedekatan itu dalam arti kuasa Allah, yakni kalau urat nadi atau pembuluh darah manusia yang menyalurkan darah dari jantungnya merupakan sesuatu yang sangat besar peranannya dalam hidup manusia, maka kuasa Allah jauh lebih besar dari itu. ${ }^{28}$

e. Al-Wāqi'ah [56] 85.
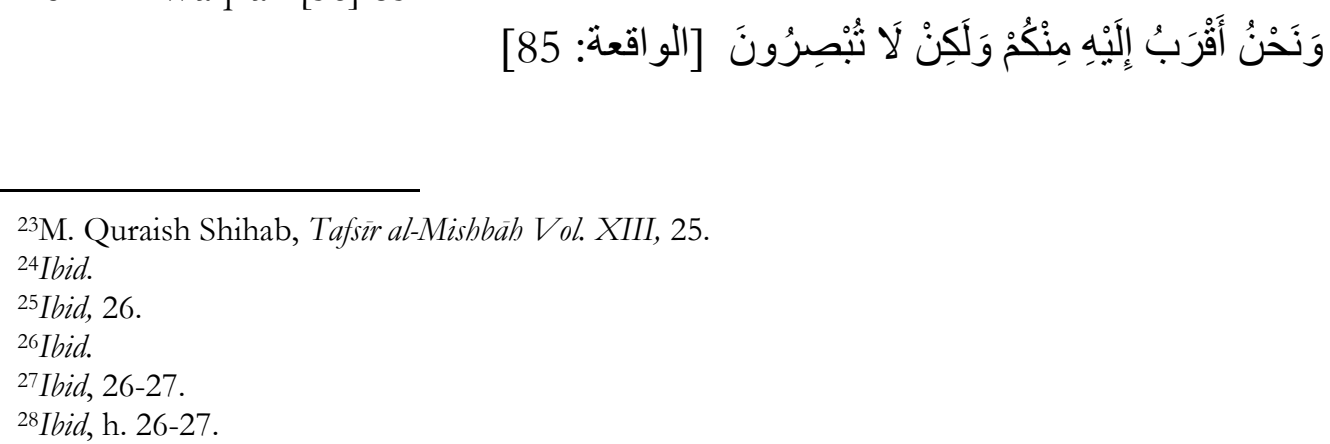
Ketika menjelaskan ayat ini, Quraish Shihab, menghubungkan dengan ayat sebelumnya, yaitu 83-84 dan ayat sesudahnya. Dengan ayat itu dinyatakan bahwa manusia adalah hambahamba yang dikuasai dan dimiliki sepenuhnya oleh Allah. Dia-lah sendiri mengatur hidup dan mati mereka. Karena itu ayat-ayat di atas bagaikan menyatakan: Maka mengapa-sekali lagimengapa saat nyawa telah sampai ke kerongkongan, kamu tidak mengembalikannya ke keadaan dan ke tempanya semula jika kamu tidak akan diberi balasan oleh Allah, atau jika kamu bukan hamba-hamba-Nya tidak berdaya. Bukankah ketika itu kamu melihat dan Kami pun ada di dekat kamu walau kamu tidak melihat Kami. ${ }^{29}$

Berdasarkan penjelasan ayat di atas, tampaknya jika dipahami penafsiran Quraish Shibab terhadap ayat 85 surah al-Wāqi'ah ini, ia tidak memberikan penjabaran makna lain terhadap kata وَنَحْنُ أَفْرَبُ selain arti kata itu sendiri secara bahasa yaitu Kami Lebih Dekat. Hal ini dapat dipahami dari uraian beliau di atas "Bukankah ketika itu kamu melihat dan Kami pun ada di dekat kamu walau kamu tidak melihat Kami”. Namun ketika menafsirkan surah Qāf [50]: 16, di bagian yang lalu dikatakan Kami Lebih Dekat, maksudnya malaikat-malaikat Kami yang lebih dekat.

\section{Makna Allah Bersama Dengan Makhluk-Nya}

Kebersamaan Allah atau ma'iyyatulläh dengan makhluk atau hamba-Nya adalah merupakan pernyataan atau informasi Allah swt. sendiri yang terdapat di beberapa surah dan ayat Alquran. Ayat-ayat tersebut seperti al-Baqarah [2] 153, 194, an-Nisā [4] 108, al-Anfāl [8] 19, 46, 66, at-Taubah [9] 36, 123, an-Nahl [16] 128, al-'Ankabūt [29] 69, al-Hadīd [57] 4.

a. al-Baqarah [2] 153, 194.

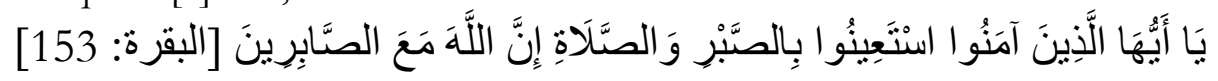

Ayat ini menyeru orang-orang mukmin agar meminta pertolongan kepada Allah melalui sabar dan shalat, karena Allah bersama orang-orang yang sabar. Menurut Quraish Shihab, Allah bersama orang-orang yang sabar mengisyaratkan bahwa jika seseorang ingin teratasi penyebab kesedihan dan kesulitannya, jika ia ingin berhasil memperjuangkan kebenaran dan keadilan, ia harus menyertakan Allah dalam setiap langkahnya. Ia harus bersama Allah dalam kesulitan dan dalam perjuangannya. Ketika itu Allah Yang Maha Mengetahui, Maha Perkasa, lagi Maha Kuasa pasti membantunya karena Dia pun telah bersama hamba-Nya. Tanpa kebersamaan itu, kesulitan tidak akan tertanggulangi bahkan tidak mustahil kesulitan diperbesar oleh setan dan nafsu amarah manusia sendiri. ${ }^{30}$

Penjelasan di atas dapat dipahami bahwa Allah dalam penafsiran Quraish Shihab diyakini dapat bersama dengan hamba-Nya-sebagaimana Allah menginformasikan demikian—dalam ayat di atas. Kebersamaan Allah di sini terhadap hamba-Nya yang sabar dan shalat, tidak dinyatakan sebagai penyatuan antara Allah dengan hamba-Nya, tetapi kebersamaan dengan sifat Allah Yang Maha Mengetahui, Maha Perkasa, lagi Maha Kuasa dalam memberikan pertolongan terhadap hamba-Nya yang menjadikan sabar dan shalat sebagai sarana meminta pertolongan kepada Allah dalam mengatasi kesulitan atau masalah hidupnya, tanpa demikian ia tidak dapat berbuat apa-apa dalam menjalani perjuangannya.

Menurut Quraish Shihab, dalam Alquran menetapkan empat bulan dalam setahun yang merupakan bulan-bulan Haram, yakni bulan-bulan yang dihormati, yang mengantar kepada lahirnya larangan-larangan tertentu yang biasanya dibolehkan pada bulan yang lain. Keempat bulan dimaksud adalah Muharram (bulan pertama), Rajab (bulan7), Dzulqa'dah (bulan 11) dan Dzulhijjah (bulan 2) dari penanggalan Qamariyah. ${ }^{31}$

Allah menyatakan dalam ayat ini bulan haram di mana kamu mengadakan umrah qadha ini berhadapan yakni pengganti dari bulan haram di mana kamu pada tahun yang lalu (enam Hijriyah/627 M.) dihalangi oleh kaum musyrikin. Bisa juga kata bulan haram dipahami dalam

\footnotetext{
${ }^{29}$ M. Quraish Shihab, Tafsì al-Mishbäh Vol. XIII, 389.

${ }^{30}$ Ibid, 434.

${ }^{31}$ M. Quraish Shihab, Tafsìr al-Mishbāh Vol. l, op.cit, 510.
} 
arti keempat bulan haram, sehingga penggalan ayat di atas berarti penghormatan terhadap bulan haram wajib bagi yang menghormati bulan haram. Adapun bagi yang tidak menghormati, tidak berlaku baginya ketentuan-ketentuan yang berkaitan dengan larangan membunuh atau perang, dan karena itu berlaku terhadap mereka hukum qishāsh, yakni perlakuan yang sama. Yang tidak menghormati maka dia pun tidak dihormati. Oleh sebab itu, barang siapa yang melakukan ageresi terhadap kamu pada bulan haram atau di luarnya, maka lakukan pula agresi pembalasan yang persis sama atau seimbang dengan agresinya terhadap kamu. ${ }^{32}$

Pada akhir ayat diingatkan dengan pesan bertakwalah kepada Allah dalam arti berhatihatilah jangan sampai siksa dan atau sanksi Allah menimpa kamu, karena itu jangan sampai kamu melampaui batas dalam membalas, dan hendaklah semua mengetahui bahwa Allah bersama orang-rang yang bertakwa dengan dukungan bimbingan dan anugerahnya. ${ }^{33}$

Berdasarkan penjelasan penggalan ayat terakhir, yakni Bertakwalah kepada Allah dan ketabuilah, bahwa Allah beserta orang-orang yang bertakwa, maka kebersamaan Allah bagi Quraish Shihab dalam ayat ini dipahami sebagai kebersamaan dukungan dan anugerah terhadap mereka. Namun apa yang dimaksud dengan dukungan dan anugerah di sini masih bersifat luas atau umum. Sebab apa pun yang diterima atau keadaan yang dialami oleh seseorangsepanjang itu positif atau kebaikan — adalah merupakan dukungan dan anugerah bagi yang bersangkutan. Allah selalu memberikan solusi atau jalan kemudahan serta anugerah (rejeki) kepada siapa saja yang bertakwa kepada-Nya dengan cara yang tidak diduga atau diperidiksi sebelumnya.( QS. 65: 2).

b. An-Nisā [4] 108.

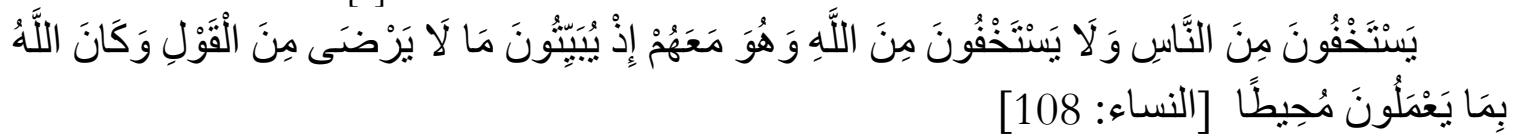

Menurut Quraish Shihab, kandungan ayat ini menjelaskan salah satu sebab mengapa ayat yang lalu (107) melarang berdebat untuk membela orang-orang yang sengaja lagi tekun dan terus, menerus mengkhianati dirinya. Mereka, yakni orang-orang yang berkhianat seperti Thu'mah yang mencuri yang mencuri perisai itu dan semacamnya, bersembunyi dari manusia karenatakut atau malu ketahuan pengkhianatan dan dosanya, padahal manusia belum tentu mampu menjatuhkan sanksi terhadap mereka, tetapi mereka tidak bersembunyi dari Allah, yakni tidak malu dan takut kepada Allah, padahal Allah beserta mereka melalui pengetahuanNya yang menyeluruh sehingga seharusnya mereka malu dan takut kepada-Nya dengan jalan meninggalkan khianat dan dosa, karena Dia Maha Mengetahui gerak gerik dan lintasan pikiran manusia termasuk ketika diwaktu malam hari dalam keadaan gelap dan tersembunyi mereka menetapkan ucapan, yakni ketetapan hati dan keputusan rahasia yang Allah tidak ridhai, seperti merencanakan pengkhianatan dan kejahatan. Dan Allah adalah sejak dulu hingga kini dan masa dating Maha Meliputi, pengetahuan-Nya, peliputan yang menyeluruh menyangkut apa, yakni segala sesuatu yang mereka kerjakan, lahir dan batin, kebajikan maupun keburukan. ${ }^{34}$

Lebih jauh Quraish Shihab menjelaskan Maha Meliputi pengetabuan-Nya mengandung makna bahwa tidak ada sesuatu pun yang dapat luput dari pengetahuan Allah, dari yang besar hingga sekecil apa pun. Jika pengetahuan-Nya meliputi segala sesuatu dan kekuasaan-Nya demikian juga, tidak ada satu perincian perbuatan yang luput dari perhitungan-Nya, kecuali jika Dia menghendaki untuk memaafkan dan mengampuni. ${ }^{35}$

Berkaitan dengan konsep kebersamaan dalam penelitian ini, bagi Quraish Shihab Allah benar-benar beserta mereka melalui ilmu atau pengetahuan-Nya yang menyeluruh sehingga seharusnya mereka malu dan takut kepada-Nya dengan jalan meninggalkan khianat dan dosa,

\footnotetext{
${ }^{32}$ Ibid, 510-511.

${ }^{33}$ Ibid, 511.

${ }^{34}$ M. Quraish Shihab, Tafsì al-Mishbāh Vol. ll, op.cit, 706.

${ }^{35}$ Ibid.
} 
karena Dia Maha Mengetahui gerak gerik dan lintasan pikiran manusia. Kebersamaan Allah dengan sifat Ilmu-Nya yang meliputi segala sesuatu ini , menyebabkan manusia tidak dapat menyembunyikan segala perbuatan baik yang tampak maupun tersembunyi semuanya tidak luput dari pengawasan dan pengetahuan Allah.

c. Al-Anfāl [8] 19, 46, 66.

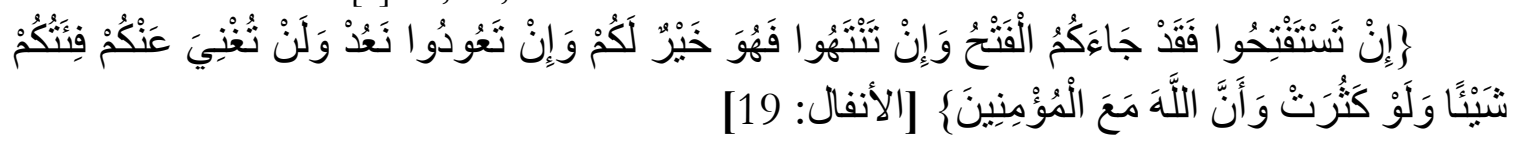

Menurut Quraish Shihab, pembicaraan ayat di atas mengarah kepada orang-orang kafir bahwa jika kamu hai orang kafir, pada suatu ketika memohon kepada Allah keputusan tentang siapa yang benar apakah kamu atau Nabi Muhammad saw., sebagaimana kamu lakukan sebelum berkecamuknya Perang Badr, maka telah datang kepada kamu keputusan itu dengan kemenangan yang dianugerahkan Allah kepada kaum muslim dan kekalahan kamu. Ini membuktikan bahwa Allah tidak merestui sikap dan perbuatan kalian. Karena itu berhentilah dari perbuatan buruk kamu dan jika kamu berhenti melakukan hal-hal yang tidak direstui Allah, maka itulah yang baik bagi kamu; dan jika kamu tidak berhenti dan kembali melakukan kedurhakaan serupa, niscaya Kami kembali pula mengalahkan kamu dan kelompok yang kamu andalkan sekali-kali tidak akan mencukupi kamu sedikit pun untuk membela dan menolak bahaya atas kamu walau jumlah personil dan perlengkapan mereka banyak dan sesungguhnya Allah beserta, yakni mendukung orang-orang mukmin yang mantap imannya. ${ }^{36}$

Penafsiran Quraish Shihab di atas memberikan kejelasan bahwa kebersamaan atau kesertaan Allah di sini adalah dengan memberikan dukungan terhadap orang-orang mukmin yang mantap imannya. Jika dipahami dari sudut sejarah awal perjuangan umat Islam, ayat ini mengingatkan peristiwa Perang Badr bagaimana perjuangan umat Islam saat mempertahankan tegaknya agama Islam di tanah Arab dari serangan orang-orang kufur Quraisy yang kekuatan mereka tidak sebanding dengan kekuatan umat Islam. Namun karena keimanan umat Islam sangat mantap, sehingga kebersamaan atau kesertaan Allah selalu mengiringi langkah perjuangan mereka. Kemenangan gemilang yang dianugerahkan Allah kepada kaum mukmin pada Perang Badr adalah karena ketaatan mereka mengikuti petunjuk Allah dan Rasul-Nya. Kebersamaan berupa dukungan Allah di sini jika dipahami tidak terbatas pada orang-orang mukmin di masa Rasulullah saja, tetapi juga bisa dialami oleh orang-orang mukmin lainnya sepanjang mereka patuh dan mantap imannya. Kebersamaan Allah selanjutnya disebutkan pada ayat 46 sebagai berikut:

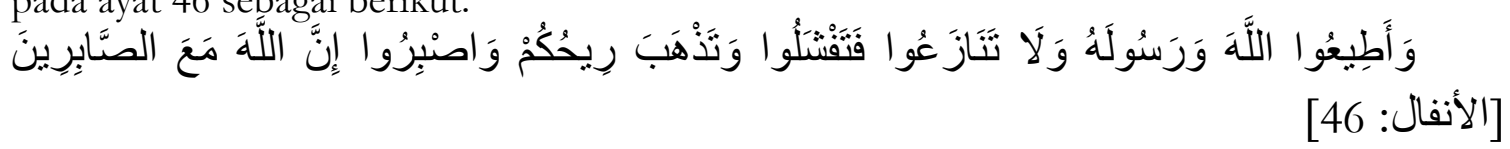

Ayat ini berisi perintah kepada orang beriman agar patuh dan tunduk kepada Allah dan Rasul-Nya serta menjauhi berbantah-bantahan karena berakibat

dapat menghilangkan kekuatan yang ada, juga diperintahkan agar mereka bersabar dalam berbagai hal.

Menurut Quraish Shihab, ayat 45 dan 46 dalam surah al-Anfāl ini memiliki keterkaitan yang jelas. Ayat 45 memerintahkan untuk berteguh hati dan ayat 46 memerintahkan agar

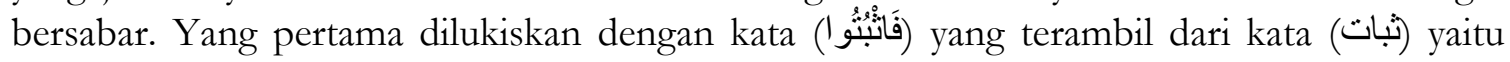
kemantapan di satu tempat sehingga tidak beranjak darinya, dan yang dimaksud adalah melanjutkan perjuangan, tidak lari dan tidak meragukan nilai-nilai yang diperjuangkan. Adapun yang kedua yaitu perintah bersabar, ia berkaitan dengan ketabahan menghadapi kesulitan dan ancaman yang dapat melemahkan diri atau jiwa. Dengan demikian dapat dikatakan bahwa perintah pertama lebih umum dari perintah kedua. ${ }^{37}$

${ }^{36}$ M. Quraish Shihab, Tafsir al-Mishbāh Vol. IV, op.cit, 488-489.

${ }^{37}$ M. Quraish Shihab, Tafsìr al-Mishbäh Vol. IV, op.cit, 553. 
Perintah kedua yang berisi tentang kesabaran dijelaskan oleh Quraish Shihab dan taatilah Allah Yang Mahakuasa dan Rasul-Nya, yang memipin kamu dalam keadaan damai dan perang dan janganlah kamu berselisih berbantah-bantahan, yang menyebabkan kamu menjadi gentar, lemah dan mengendor semangat kamu bahkan gagal dan lumpuh dan hilang kekuatan kamu dan bersabarlah menghadapi segala situasi dan tantangan. Sesungguhnya Allah bererta orang-orang yang sabar, yakni selalu mengetahui keadaan mereka dan membantu mereka. ${ }^{38}$

Dengan penjelasan di atas dapat diketahui bahwa kebersamaan Allah di sini adalah kebersamaan atau kesertaan Allah atas hamba-Nya melalui sifat Ilmu-Nya tentang keadaan mereka dan membantu atau memberi pertolongan kepada mereka dalam berbagai hal. Kemudian kebersamaan Allah berikutnya disebutkan dalam ayat 66 sebagai berikut:

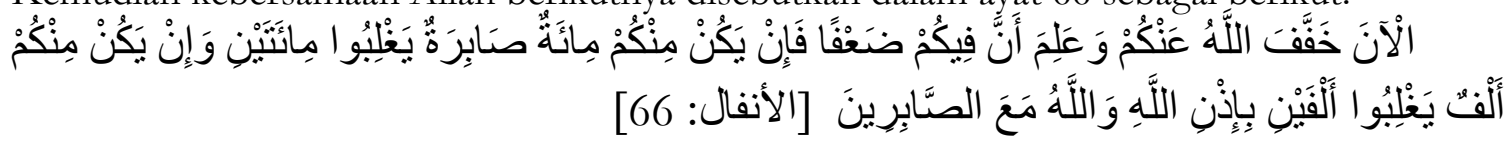

Menurut Quraish Shihab, sekarang-pada saat turunnya ayat ini-Allah telah meringankan atas kamu ketentuan satu banding sepuluh (lih. ayat 65) dalam menghadapi musuh karena rahmat dan kasih saying-Nya kepada kamu; dan sebenarnya sejak dahulu Dia telah mengetahui bahwa pada diri atau lingkungan kamu ada beberapa kelemahan. Maka sejak sekarang, jika ada di antara kamu—wahai orang-orang yang beriman-sebanyak seratus orang yang sabar dan tabah, niscaya mereka dapat mengalahkan dua ratus orang kafir atau siapa saja yang harus diperangi; dan jika ada di antara kamu seribu orangyang sabar, niscaya mereka dapat mengalahkan dua ribu orang kafir dengan seizing Allah. Ini disebabkan kamu sabar dan yakin, sedang Allah beserta orang-orang yang sabar. Dia mendukung dan melimpahkan karunia-Nya untuk mereka. ${ }^{39}$

Berdasarkan penafsiran di atas dapat dipahami bahwa kesabaran dalam menghadapi sesuatu dan keyakinan seseorang terhadap janji Allah merupakan sebuah kekuatan yang luar biasa, sehingga tadinya kaum mukmin yang terbilang lemah ternyata dapat mengalahkan jumlah musuh dari pihak kafir Quraisy yang berlipat ganda. Ini disebabkan karena mereka memiliki jiwa yang sabar dan keyakinan yang mantap kepada Allah, maka Allah menyertai perjuangan mereka ketika menghadapi musuh-musuhnya di medang perang. Kesertaan atau kebersamaan Allah di sini oleh Quraish Shihab dimaknai sebagai pemberian dukungan dan pelimpahan rahmat-Nya kepada kaum mukmin sehingga mereka memperoleh kemenangan.

d. At-Taubah [9] 36, 123.

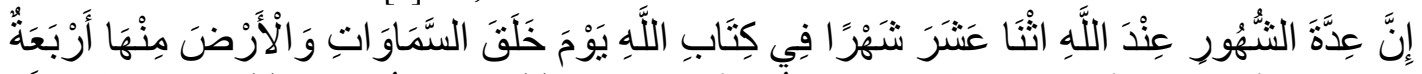

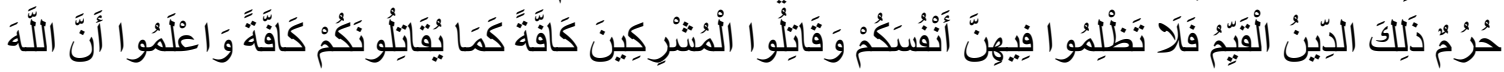

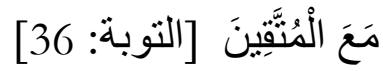

Ayat di atas menyebut hitungan bulan, larangan melakukan aniaya dalam bulan-bulan tertentu dan perintah memerangi kaum musyrik sebagaimana mereka memerangi orang-orang beriman. Menurut Quraish Shihab, Allah berfirman menjelaskan bahwa sesungguhnya batas yang tidak dapat ditambah atau dikurangi menyangkut bilangan bulan di sisi Allah, yakni menurut perhitungan dan ketetapan-Nya, adalah dua belas bulan tidak berlebih dan tidak berkurang, tidak juga dapat diputarbalikkan tempatnya. Bilangan itu berada dalam ketatapan Allah sejak dahulu di waktu Dia pertama kali menciptakan langit dan bumi yang atas keberadaannya waktu pun tercipta. Dua belas bulan itu di antaranya terdapat empat bulan tertentu, bukan sekadar bilangannya empat dalam setahun. Keempat tertentu itu adalah haram, yakni agung. Itulah ketetapan agama yang lurus, maka janganlah kamu menganiaya diri kamu di dalamnya, yakni dalam keempat bulan haram itu, dengan berbagai dosa apa pun dan terhadap siapa pun, antara lain dengan menambah atau mengurangi bilangan bulan. ${ }^{40}$

\footnotetext{
${ }^{38} \mathrm{Ibid}$.

${ }^{39}$ M. Quraish Shihab, Tafsì al-Mishbäh Vol. IV, op.cit, 599.

${ }^{40}$ M. Quraish Shihab, Tafsìr al-Mishbāh Vol. V, op.cit, 87.
} 
Menurut Quraish Shihab, ayat ini menetapkan bahwa Allah menjadikan empat bulan dalam setahun sebagai bulan-bulan haram. Kehormatan dan keagungan yang disandang oleh waktu dan tempat pada dasarnya serupa dengan kehormatan dan keagungan yang disandang oleh manusia. Kalau manusia menyandang kehormatan karena banyaknya kebaikan yang lahir darinya, seperti keimanan yang tulus dan budi pekerti yang luhur, tempata dan waktu juga mendapat keagungan dan kehormatan karena di tempat atau waktunya itu dapat lahir kebaikan yang banyak ganjaran yang melimpah. Pada waktu dan tempat itu, Allah membuka peluang besar untuk memperoleh anugerah-Nya serta melipatgandakan ganjarannya. ${ }^{41}$

Larangan menganiaya atau melakukan dosa pada keempat bulan itu bukan berarti pada bulan-bulan sisanya dosa dapat dilakukan. Tidak, yang dimaksud adalah penekanan khusus pada keempat bulan itu karena ia merupakan bulan-bulan ibadah lagi agung di sisi Allah. Karena itu pula maka beribadah pada masa-masa tersebut berdampak positif dan mengundang banyak pahala, demikian pula sebaliknya berdosa mengakibatkan murka yang besar. ${ }^{42}$

Boleh jadi larangan di atas-menurut Quraish Shihab-dipahamai pula sebagai larangan berperang membela diri dari penganiayaan orang lain. Karena itu, untuk menampik pemahaman itu, ayat ini selanjutnya menyatakan dan perangilah orang-orang musyrik semuanya sebagaimana mereka pun memerangi kamu semuanya kapan pun perang itu harus kamu lakukan; dan ketabuilah bahwa Allah bersama orang-orangyang bertakwa. ${ }^{43}$

Jika diperhatikan uraian Quraish Shihab dalam ayat 36 surah at-Taubah ini, ia tidak menyebutkan secara tegas bagaimana bentuk atau wujud kebersamaan Allah bagi hambahamba-Nya yang bertakwa. Quraish Shihab dalam ayat ini lebih fokus menjelaskan menyebut hitungan bulan, larangan melakukan aniaya dalam bulan-bulan tertentu dan perintah memerangi kaum musyrik sebagaimana mereka memerangi orang-orang beriman. Namun bila dicermati seluruh uraiannya terkait ayat ini, ia menjelaskan bahwa Allah menjadikan empat bulan dalam setahun sebagai bulan-bulan haram. Kehormatan dan keagungan yang disandang oleh waktu dan tempat pada dasarnya serupa dengan kehormatan dan keagungan yang disandang manusia.

Quraish Shihab mengibaratkan, kalau manusia menyandang kehormatan karena banyaknya kebaikan yang lahir darinya, seperti keimanan yang tulus dan budi pekerti yang luhur, tempat dan waktu juga mendapat keagungan dan kehormatan karena di tempat atau waktunya itu dapat lahir kebaikan yang banyak serta ganjaran yang melimpah. Pada waktu dan tempat itu, Allah membuka peluang besar untuk memperoleh anugerah-Nya serta melipatgandakan ganjarannya. ${ }^{44}$ Inilah bentuk kebersamaan Allah kepada orang-orang yang bertakwa dan bertaqrrub kepada Allah dengan memberikan anugerah yang berlipatganda atas ibadah yang dilakukannya pada tempat atau waktu tertentu, karena keagungan dan kehormatannya, seperti shalat di Masjid al-Haram, Masjid Nabawi, Shalat dan ibadah di bulan Ramadhan, malam Qadar dan lain-lain. Semua itu menunjukkan derajat pahala yang berbedabeda.

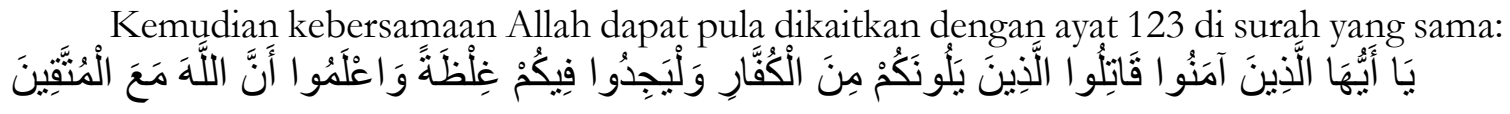

[التوبة: 123]

Menurut Quraish Shihab, ayat ini mengundang kaum beriman Hai orang-orang yang mengaku beriman! Buktikanlah keimananmu antara lain dengan berjuang karena itu perangilah orang-orang kafir yang di sekitar kamu, yakni yang bertempat tinggal di kota Madinah, dan kalau sudah tidak ada yang berada di sekitar kamu, maka yang berada sesudahnya, dan

\footnotetext{
${ }^{41}$ Ibid, 90.

42 Ibid, 89-90.

${ }^{43}$ Ibid, 87-88.

${ }^{44}$ Ibid, 90.
} 
hendaklah mereka menemui kekerasan, yakni sikap tegas, semangat juang, kesabaran dan ketabahan dari kamu. Selanjutnya hendaklah semua itu dilandasi oleh ketakwaan kepada Allah, bukan untuk maksud meraih harta, kedudukan atau popularitas dan ketahuilah bahwa Allah bersama orang-orang yang bertakwa. Karena itu, jangan takut, jangan melemah atau berputus asa. $^{45}$

Dijelaskan pula, bahwa perintah ayat ini yang ditujukan kepada kaum beriman-bukan kepada Nabi Muhammad saw.-melahirkan kesan bahwa Nabi Muhamma saw., tidak lagi

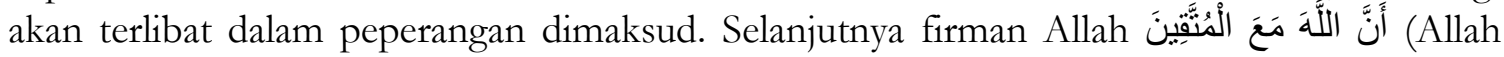
bersama orang-orang yang bertakwa) dapat juga semacam hiburan kepada kaum muslim bahwa, walaupun Rasul saw., sebentar lagi akan meninggalkan kalian, Allah swt. tetap akan bersama kalian dengan bantuan, pertolongan dan dukungan-Nya selama kalian bertakwa. ${ }^{46}$

e. An-Nahl [16] 128.

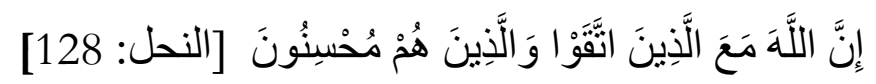

Ayat ini-menurut Quraish Shihab—punya hubungan dengan ayat sebelumnya, yaitu 126-127. Ayat itu dimulai dengan "dan", yakni dan apabila kamu membalas, yakni menjatuhkan hukuman kepada siapa yang menyakiti kamu, maka balaslah (hukumlah dia), persis sama dengan siksaan yang ditimpakan kepada kamu atau kesalahan yang mereka lakukan. Jangan sedikit pun melampaui batas. Akan tetapi jika kamu bersabar dan tidak membalas, maka sesungguhnya itulah yang lebih baik bagi para penyabar baik di dunia maupun di akhirat kelak. Karena itu wahai Nabi Muhammad—sebagai manusia sempurna dan teladan- laksanakanlah tuntunan ini dan bersabarlah menghadapi gangguan kaummu dan dalam melaksanakan tugas-tugas dakwah dan tiadalah kesabaranmu itu akan mencapai hasil yang memuaskan melainkan dengan pertolongan Allah kepadamu. Karena itu, andalkanlah Allah dan mohonlah pertolongan-Nya dan janganlah engkau bersedih hati terhadap keengganan mereka beriman dan jangan pula engkau bersempit dada, yakni kesal walau sedikit pun terhadap apa yang terus- menerus mereka tipu dayakan guna merintangi dakwahmu. ${ }^{47}$ Dengan mengutip pendapat asy-Sya'rawi, Quraish Shihab menjelaskan pula ayat sebelumnya

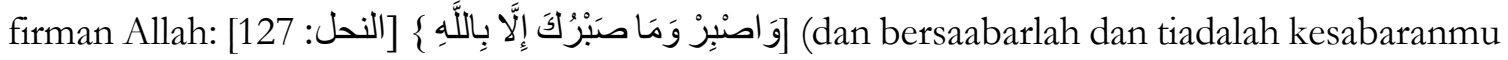
melainkan dengan pertolongan Allah) dipahami sebagai perintah untuk membulatkan niat melaksanakn kesabaran. Jangan duga bahwa engkau yang melahirkan kesabaran. Allah hanya menuntut dirimu agar engkau mengarah kepada kesabaran, sekadar mengarah dan membulatkan niat. Jika itu telah engkau lakukan, Allah swt., akan melahirkan dalam dirimu bisikan-bisikan baik yang membantumu sabar, mempermudah bagimu serta menjadikan engkau rela menerima apa yang engkau hadapi. Dengan demikian, kesabaranmu menjadi sabar yang indah tanpa gerutu dan tanpa pembangkaangan. ${ }^{48}$

Merurut Quraish Shihab, upaya mereka (kaummu, kufur Quraisy) tidak akan berhasil dan mereka pun tidak akan mencelakakanmu, karena engkau adalah seorang yang bertakwa dan sesungguhnya Allah beserta orang-orang yang bertakwa, yakni yang menjaga diri dari murka-Nya dengan cara menjauhkan diri dari larangan-Nya dan orang-orang yang mereka adalah para muhsinin. ${ }^{49}$

Ayat-ayat di atas seakan-akan berpesan kepada Nabi Muhammad saw. bahwa: Wahai Nabi, engkau adalah pemimpin para mubsin sehingga Allah pasti bersamamu. Dengan demikian, engkau akan meraih kemenangan dan kekalahan akan diderita musuh-musuhmu.

\footnotetext{
${ }^{45}$ M. Quraish Shihab, Tafsìr al-Mishbāh Vol. V, op.cit, 292.

${ }^{46}$ Ibid, 293.

${ }^{47}$ M. Quraish Shihab, Tafsìr al-Mishbāh Vol. VI, op.cit, 778.

${ }^{48}$ Ibid, 780.

${ }^{49}$ Ibid. 638.
} 
Berdasarkan uraian ayat di atas, dapat dikatakan bahwa kebersamaan atau kesertaan Allah dengan orang-orang yang bertakwa dan orang-orang yang mereka adalah para muhsinin berupa pertolongan dan bantuan Allah melahirkan kesabaran sebagai buah dari ketakwaan dan perilaku ibsan yang mereka lakukan. Allah swt., akan melahirkan dalam diri mereka bisikan-bisikan baik yang membantu mereka sabar, mempermudah serta menjadikan mereka rela menerima apa yang dihadapi. Ketika mereka memperoleh kesabaran, maka kesabaran itu sendiri sebagai sebuah kekuatan yang dapat mengalahkan musuh-musuh mereka yang kesenuanya itu tidak lain adalah atas kebersamaan atau kesertaan Allah, yaitu pertolongan atau bantuan serta kemudahan bagi mereka.

f. Al-'Ankabūt [29] 69.

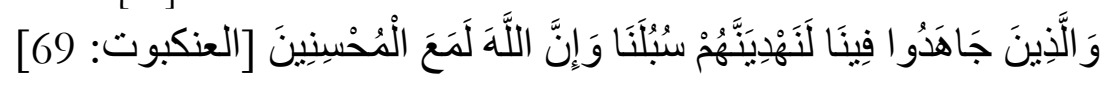

Dalam Tafsir al-Mishbăh, Quraish Shibab menjelaskan ayat di atas bagaikan menyatakan "Orang-orang yang Kami uji tetapi enggan berjihad dan bermujahadah, namun mengikuti hawa nafsu mereka dan berfoya-foya dalam kelezatan dunia, mereka itu mendapat nista dan siksa. Dan orang-orang yang berjihad mengarahkan kemampuannya dan bersungguh-sungguh memikul kesulitan, sehingga jihad mereka itu berada pada sisi Kami karena mereka melakukannya demi Allah, maka pasti Kami tunjuki mereka jalan-jalan Kami, yakni Kami mengantar mereka menuju aneka jalan kedamaian dan kebahagiaan. Dan sesungguhnya Allah benar-benar beserta, yakni membantu, melimpahkan rahmat dan kasih sayang buat al-mubsinin, yakni orang-orang yang selalu berbuat kebajikan. ${ }^{50}$

Secara singkat dapat dipahami bahwa kebersamaan atau kesertaan Allah atas hambaNya al-mubsinin adalah berupa membantu, melimpahkan rahmat dan kasih sayang buat mereka dalam berjihad dan menempuh jalan yang diridhai Allah swt.

g. Al-Hadīd [57] 4.

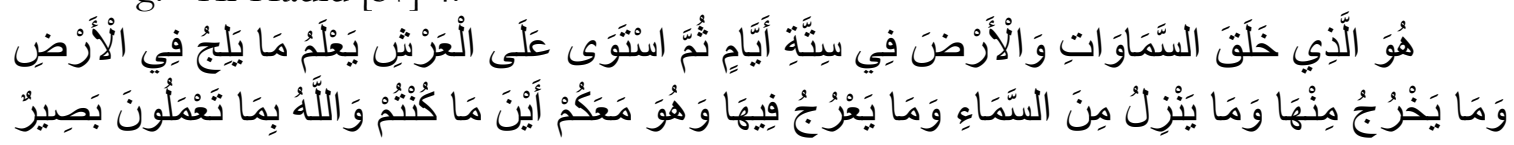

[الحديد: 4

Ayat ini menurut Quraish Shihab menguraikan penciptaan Allah terhadap alam raya serta sekelumit dari rincian pengetahuan-Nya yang menyeluruh itu. Ayat tersebut menegaskan hanya Dia-lah yang menciptakan langit yang berlapis tujuh itu dan bumi yang terhampar inialam raya seluruhnya_dalam enam hari, yakni masa atau periode. Kemudian Dia bersemayam di atas 'Arsy, yakni Dia berkuasa dan mengatur segala yang diciptakan-Nya sehingga berfungsi sebagaimana yang Dia kehendaki. Jangan duga bahwa setelah selesai diciptakan, Dia abaikan atau Dia tidak mengetahui lagi keadaan ciptaan-Nya. Tidak demikian! Dia dari saat ke saat dan secara kesinambungan mengetahui apa yang masuk ke dalam bumi seperti air, berbagai kekayaan alam, fosil-fosil makhluk yang telah mati, benih dan lain-lain.

Dia mengetahui pula apa yang keluar darinya, seperti tumbuhan, binatang, barang tambang, air dan sebagainya. Dia mengetahui juga apa yang turun dari langit, seperti malaikat, hujan dan apa yang naik kepadanya, seperti uap, do'a, amalan-amalan manusia, dan bukan hanya itu, tetapi Dia juga selalu bersama kamu dengan pengetahuan dan kuasa-Nya di mana saja kamu berada. Dan Allah Maha Melihat apa yang kamu kerjakan baik secara lahir maupun secara batin, nyata maupun tersembunyi. ${ }^{51}$

Bagi Quraish Shihab, kata (مَ) bersama, tidak selalu berarti bercampur dan menyatunya

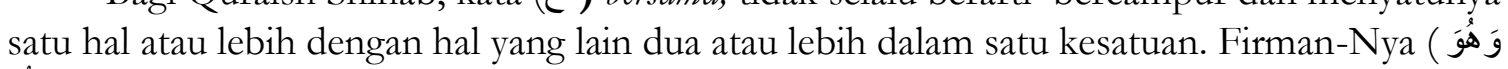
)مَكَكُمْ Dia (Allah bersama) bersama kamu, jika ia ditujukan kepada makhluk secara umum,

${ }^{50}$ M. Quraish Shihab, Tafsìr al-Mishbāh Vol. X, op.cit, 141-142.

${ }^{51}$ M. Quraish Shihab, Tafsìr al-Mishbāh Vol. XIII, op.cit, 405-406. 
kebersamaan itu adalah pengetahuan-Nya, dan bila ditujukan kepada orang-orang mukmin, kebersamaannya adalah batuan dan dukungannya. Itulah yang dimaksud antara lain ketika Allah menyatakan kebersamaan-Nya dengan Musā dan Hārūn (baca QS. Thaha [20: 46), dan itu juga yang dimaksud Nabi saw. yang berkata kepada Sayyidina Abū Bakar ketika berhijrah

sesungguhnya Allah bersama kita (QS. at-Taubah [19]: 40. ${ }^{52}$

\section{Sarana Kedekatan dan Kebersamaan Dengan Allah}

Sebenarnya banyak hal yang bisa dilakukan, karena ibadah dalam Islam itu memiliki cakupan yang sangat luas, sehingga penulis kemukakan di sini hanya beberapa di antara ayatayat yang telah dipaparkan di bagian terdahulu, hal ini mengingat keterbatasan waktu.

\section{Isti'anah,ash-Shabr, dan ash-Shalät}

Ketiga istilah di atas terdapat dalam surah a-Baqarah [2]: 153. Isti'anah berarti meminta pertolongan maksudnya berdo'a kepada Allah, yaitu menyampaikan keingian seorang hamba kepada Allah agar segenap permintaanya dapat dikabulkan. Perintah berdo'a di dalam Alquran disebutkan dalam surah al-A'raf: 29

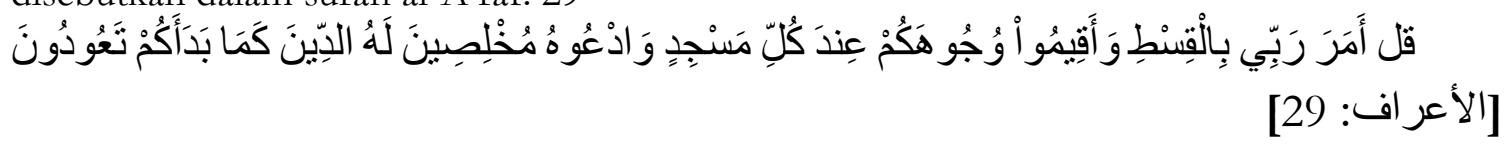

Menurut Quraish Shihab, perintah berdo'a dalam ayat ini maksudnya adalah beribadahlah dengan mengikhlaskan ketaatan kepada-Nya, yakni jangan mempersekutukanNya dengan sesuatu walaupun dengan sedikit persekutuan pun. ${ }^{53}$ Ini dapat dipahami karena do'a itu sendiri termasuk ibadah, bahkan intinya ibadah. Karena itu dalam berdo'a kepada Allah itu antara lain tidak sombong dan merendahkan diri dihadapan Allah dengan penuh harap supaya terkabul.

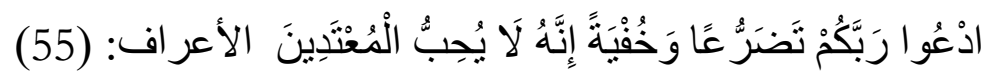

Menurut Quraish Shihab, berdo'a kepada Allah dengan merendahkan diri dan merahasiakan, maksudnya berdo'alah kepada Tuhan yang selalu membimbing dan berbuat baik kepadamu serta beribadahlah secara tulus sambil mengakui keesaan-Nya dengan berendah diri menampakkan kebutuhan yang sangat mendesak, serta dengan merahasiakan, yakni memperlembut suara kamu seperti halnya orang yang merahasiakan sesuatu. Siapa yang enggan berdo'a atau mengabaikan tuntunan ini, dia telah melampaui batas dan sesungguhnya Allah tidak menyukai, yakni tidak melimpahkan rahmat kepada orang-orang yang melampaui batas. ${ }^{54}$

Media selanjutnya adalah ash-sabr (sabar,tabah hati) banyak disebut dalam Alquran, karena sifat ini mengisyaratkan pelakunya memiliki jiwa yang kuat dan tenang dalam menghadapi sesuatu. Menurut Quraish Shihab, ash-sabr yang dimaksud mencakup banyak hal seperti sabar menghadapi ejekan dan rayuan, sabar dalam melaksanakan perintah dan menjauhi larangan, sabar dalam petaka dan kesulitan serta sabar dalam berjuang menegakkan kebenaran dan keadilan. ${ }^{55}$ Banyak pujian Allah yang diberikan kepada orang-orang yang sabar ini, karena sifat sabar itu sendiri dapat mengantarkan pemiliknya selalu dekat kepada Allah.

Sarana berikutnya untuk dekat kepada Allah swtr. adalah melalui shalat. Perintah shalat ini merupakan perintah pokok yang banyak disebutkan dalam Alquran, di antaranya surah Hūd 114; al-Isra: 78, Thāha: 14, Luqman: 17 dan lain-lain. Dalam surah Thāha [20]: 14 disebutkan sebagai berikut:

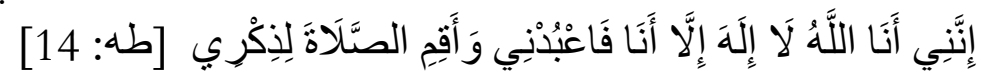

\footnotetext{
${ }^{52}$ Ibid, 406.

${ }^{53}$ M. Quraish Shihab, Tafsìr al-Mishbäh Vol. IV , op.cit, 81.

${ }^{54}$ Ibid, 142-143.

${ }^{5}$ Ibid, vol. 1, 434.
} 
Menurut Quraish Shihab, terdapat perbedaan pendapat ulama tentang makna (لَّْْرِي). Bukan pada kata dzikr tetapi juga pada huruf Lām (li) yang mendahului kata driker itu. Kata driker ada yang memahaminya dalam arti dzikr dengan ucapan, ada pula dzikr dalam arti dzikr qalbu. Sementara huruf Làm ada yang memahaminya dalam arti agar/supaya sehingga penggalan ayat ini memerintahkan melaksanakan shalat agar dengannya seseorang selalu mengingat kehadiran Allah. Shalat yang baik dan benar akan mengantar seseorang mengingat kebeasaran Allah dan mengantarnya untuk melaksanakan perintah-perintah-Nya dan menjauhi larangan-Nya. ${ }^{56}$ Dengan demikian shalat termasuk dzikir paling utama yang berarti melakukan aktifitas dalam upaya ingat kepada Allah. Jika shalat tersebut dikategorikan sebagai bagian dzikir, maka mengingat Allah itu mengantarkan seseorang taqarrub (mendekatkan diri) kepada-Nya.

a. Takwa pada Allah

Perintah bertakwa kepada Allah cukup banyak disebutkan dalam Alquran, di antaranya al-Baqarah [2]: 197; al-Māidah [5]: 2; al-A'raf [7]: 26; at-Taubah [9]: 108; al-Hajj [22]: 37; alFath [48]: 26; al-Mujādilah [58]: 9; al-Muddatsir [74]: 56 dan lain-lain. Hal ini mengisyaratkan bahwa takwa seseorang kepada Allah swt. dapat mengantarnya dekat kepada Rabbnya. Takwa sering diartikan menjunjung tinggi perintah Allah dan menjauhi segala larangan-Nya, dan sebaik-baik bekal adalah takwa.

Menurut Quraish Shihab, kata takwa berarti menghindar; orang bertakwa berarti orang yang menghindar. Takwa mencakup tiga tingkat penghindaran. Pertama, menghindar dari kekufuran dengan cara beriman kepada Allah. Kedua, berupaya melaksanakan perintah Allah sepanjang kemampuan yang dimiliki dan menjauhi larangan-Nya. Ketiga,menghindar dari segala aktifitas yang menjauhkan pikiran dari Allah.

Berdasarkan surah al-Baqarah [2] ayat3-5, Quraish Shihab menyebutkan beberapa kriteria orang-orang yang bertakwa. Pertama, percaya kepada yang gaib. Kedua mereka yang melaksanakan shalat secara benar dan berkesinambungan. Ketiga, menafkahkan, yakni mengeluarkan apa yang dimiliki dengan tulus setiap saat dan secara berkesinambungan yang wajib atau yang sunnah. Keempat, percaya menyangkut apa yang diturunkan kepadamu (Muhammad), yakni Alquran dan apa yang diturunkan kepada nabi sebelummu, yakni Taurat, Injil dan Zabur serta dengan keniscayaan kehidupan hari akhirat. ${ }^{57}$ Alquran menyebut mereka orang-orang yang beruntung.

b. Memenuhi perintah Allah dan Beriman Kepada-Nya

Dalam surah al-Baqarah [2]: 186 menyebutkan orang yang dekat kepada Allah, selain berdo'a ia juga harus memenuhi perintah Allah dan beriman kepada-Nya. Banyak hal terkait memenuhi perintah Allah ini antara lain menghindari apa yang diharamkan Allah seperti pada makanan, pakaian dan lain-lain. Ini terkait dengan terkabul tidaknya do'a seseorang.

Selanjutnya dalam ayat itu diperinthkan pula agar percaya kepada-Nya. Tidak saja mengakui keesaan-Nya tetapi juga percaya bahwa Dia akan memilih yang terbaik untuk si pemohon. Allah tidak menyia-nyiakan do'a itu, karena itu percayalah kepada Allah dan camkanlah sabda Nabi: "Berdo'alah kepada Allah disertai dengan keyakinan penuh bahwa Allah akan memperkenankan". Itu semua agar kamu selalu berada dalam kebenaran, yakni agar mengetahui jalan yang terbaik serta bertindak tepat, baik menyangkut soal dunia maupun akhirat. ${ }^{58}$

c. Berjihad di Jalan Allah

Alquran banyak menyebut jihad di jalan Allah ini, yaitu jihad dengan harta dan jihad dengan jiwa dan raga. Dalam Tafsīr al-Mishbāh, Quraish Shihab menjelaskan orang-orang

\footnotetext{
${ }^{56}$ M. Quraish Shihab, Tafsì al-Mishbāh Vo.ll, 568.

${ }^{57}$ Ibid, Vol, l, 110-111.

${ }^{58}$ Ibid. 493.
} 
yang berjihad mengarahkan kemampuannya dan secara bersungguh-sungguh memikul kesulitan sehingga jihad mereka itu berada pada sisi Kami, karena mereka melakukannya demi Allah, maka pasti Kami tunjuki mereka menuju aneka jalan kedamaian dan kebahagiaan. ${ }^{59}$

Di sisi lain, Allah memberikan kabar gembira bagi mereka memperoleh keberuntungan dan derajat yang tinggi di sisi Allah. Ini disebutkan dalam surah at-Taubah [9]: 20:

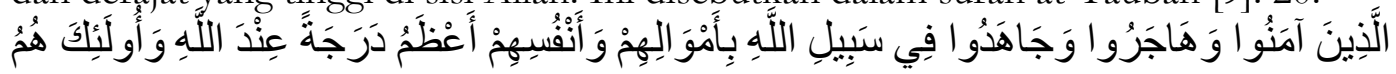

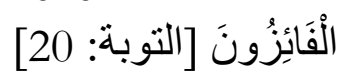

Quraish Shihab menjelaskan, orang-orang yang beriman dengan iman yang benar dan membuktikan kebenaran mereka antara lain dengan taat kepada Allah dan rasul-Nya dan berhijrah dari Mekah ke Madinah serta berjihad di jalan Allah untuk menegakkan agama-Nya dengan harta benda mereka dan diri mereka, adalah lebih agung derajatnya di sisi Allah daripada mereka yang tidak menghimpun ketiga sifat ini; mereka yang secara khusus dinamai orang-orang yang benar-benar beruntung secara sempurna ${ }^{60}$ Karena tingginya derajat mereka di sisi Allah, maka Allah menyatakan bersama mereka.

d. Berbuat Ihsān (Melakukan Kebaikan)

Berbuat Ihsān adalah kebalikan dari ifsäd atau fasäd kerusakan). Dalam Alquran surah alA'rāf [7]: 56 disebutkan sebagai berikut:

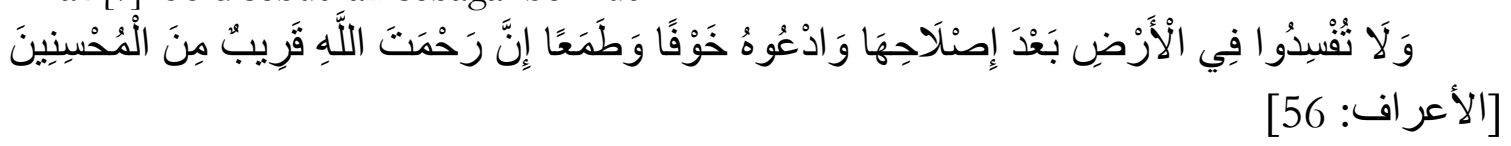

Ayat ini melarang berbuat pengrusakan di bumi. Pengrusakan adalah suatu bentuk pelampauan batas. Karena itu, ayat ini melanjutkan tuntunan ayat yang lalu dengan menyatakan: dan janganlah membuat kerusakan di bumi sesudah perbaikannya yang dilakukan oleh Allah dan atau siapa pun dan berdo'alah serta beribadahlah kepada-Nya dalam keadaan takut sehingga kamu lebih khusyuk, dan lebih terdorong untuk menaati-Nya dan dalam keadaan penuh harapan terhadap anugerah-Nya, termasuk pengabulan do'a kamu. Sesungguhnya rahmat Allah amat dekat kepada al-mubsinin, yakni orang-orang yang berbuat baik. ${ }^{61}$

Menurut Quraish Shihab, alam raya telah diciptakan Allah dalam keadaan yang sangat harmonis, serasi dan memenuhi kebutuhan makhluk. Allah telah menjadikannya baik, bahkan memerintahkan hamba-hamba-Nya untuk memperbaikinya. Salah satu perbaikan yang dilakukan Allah adalah dengan mengutus para nabi untuk meluruskan dan memperbaiki kehidupan yang kacau balau dalam masyarakat. Siapa yang tidak menyambut kedatangan rasul, atau menghambat misi mereka, dia telah melakukan salah satu pengrusakan di bumi. ${ }^{62}$ Dengan penjelasan ini, dapat dipahami bahwa pengrusakan dimuka bumi ini bisa terjadi dalam hal-hal tatanan lingkungan hidup, bisa pula terjadi kerusakan pada tataran moral masyarakat. Jika terjadi demikian, harus dilakukan upaya perbaikan yang dalam ayat ini dikaitkan dengan sifat mubsinin, karena Allah menyukai orang-orang yang berbuat kebaikan (mubsinin), bahkan Ia bersama mereka.

\section{Analisis}

Di bagian analisis ini penulis lihat dari aspek pengertian dan pemaknaan kedekatan dan kebersamaan Allah serta sarana atau media yang mengantarkan untuk dekat dengan atau bersama Allah yang dipaparkan Pada uraian sebelumnya penulis telah mengemukakan pengertian kedekatan dan kebersamaan secara bahasa atau ungkapan sehari-hari untuk memperoleh gambaran yang konkret agar tidak terjebak pada pengertian yang bermacam-

${ }^{59}$ Ibid, Vol. X,141-142.

${ }^{60}$ M. Quraish Shihab, Tafsì al-Mishbāh Vo.V, 47-48.

${ }^{61}$ M. Quraish Shihab, Tafsir al-Mishbāh Vo.lV, 143144.

${ }^{62}$ Ibid, 144 . 
macam dan terhindar dari kesan yang berlebihan. Hal ini penulis lakukan ketika mengkaji makna kedekatan dan kebersamaan Allah terhadap makhluk atau hamba-Nya dalam Tafsir alMishbäh karya munomental M. Quraish Shihab.

Selaku seorang mufassir, Quraish Shihab sangat teliti ketika berhadapan dengan sebuah ungkapan kata ataupun kalimat yang terdapat dalam ayat Alquran. Ia tidak langsung menyatakan maksud ayat secara sepontan atas dasar litterlik ayat, melainkan pertimbangan yang cermat dengan terlebih dahulu merujuk kepada kamus Alquran atau kamus bahasa dan juga pendapat ulama tafsir yang sering disebutnya, seperti Asy-Sya'rawi, al-Biqā'i, Ibn 'Asyūr, Ibn Katsīr dan lain-lain. Ini mengesankan bahwa Quraish Shihab berupaya untuk menemukan makna yang lebih tepat atau paling tidak mendekati maksud yang dikehendaki dari essensi atau pesan sebuah ayat.

Selanjutnya dalam pencarian makna kedekatan dan kebersamaan Allah ini-seperti diuraikan pada bagian terdahulu-umumnya di kalangan ulama salaf ${ }^{63}$ membedakan atau membagi kedekatan Allah dengan makhluk-Nya itu dalam dua hal, yaitu kedekatan secara umum dan kedekatan secara khusus. Begitu pula kebersamaan Allah dengan makhluk-Nya ada kebersamaan yang umum dan ada kebersamaan yang khusus. Quraish Shihab tampaknya tidak terpengaruh dengan adanya pembagian ini.

Bagi Quraish Shihab-ketika menafsirkan al-Baqarah [2]: 186-dengan merujuk pendapat ulama Alquran mengtakan bahwa kata "jawablah" ditiadakan di sini untuk mengisyaratkan bahwa setiap orang-meski bergelimang dalam dosa-dapat langsung berdo'a kepada-Nya tanpa perantara. Ia juga mengisyaratkan bahwa Allah begitu dekat kepada manusia, dan manusia pun dekat kepada-Nya, karena pengetahuan tentang wujud Allah melekat pada fitrah manusia, bukti-bukti wujud dan keesaan-Nya pun terbentang luas. ${ }^{64}$

Pendapat Quraish Shihab ini tampaknya ingin menyatakan bahwa semua manusia itu tanpa kecuali merasakan adanya kekuasaan atau pengaruh Tuhan dalam dirinya. Setiap manusia lahir ke dunia ini dengan membawa fitrah beragama tauhid semenjak berada di alam roh. ${ }^{65}$ Fitrah beragama tauhid ini tidak akan hilang selamanya, hanya bisa terpendam di relung hati yang sangat dalam, yang pada suatu saat akan muncul kepermukaan ${ }^{66}$ dan fitrah ini tidak bisa diganti dengan fitrah yang lain. Atas dasar ini, secara fitri manusia sudah mengenal Tuhan, hanya saja intensitas masing-masing yang berbeda setelah lahir ke dunia. Dengan demikian bisa jadi Quraish Shihab dengan alasan ini tidak memilah kedekatan Allah itu di antara umat manusia, meski ulama lain telah memilah kedekatan itu dengan istilah kedekatan khusus berdasarkan indikasi ayat yang menyebut beberapa karakter terpuji yang dimiliki hamba-Nya seperti sabar, takwa, mukmin, muhsin.

Dalam memahami makna kedekatan Allah dengan makhluk atau hamba-Nya, Quraish Shihab_-sebagaimana ulama lainnya-meski Allah dikatakan sangat dekat dengan makhluk atau hamba-Nya, tetapi tidak menjustifikasi sampai bersatunya antara Tuhan dengan hambaNya. Pemaknaan dekat yang diberikan pada prinsipnya tidak terlalu jauh berbeda dengan ulama lainnya, misalnya kedekatan rahmat-Nya bagi hamba-hamba-Nya, Maha Dekat dengan pengetahuan dan pertolongan, Kami bersama malaikat-malaikat—dengan pengetahuan Kami itu-lebih dekat kepadnya daripada urat lehernya, betapa Allah Maha Mengetahui keadaan manusia yang paling tersembunyi sekalipun.

Bagi Quraish Shihab, ayat-ayat yang menyebut dekat itu merupakan kiasan yang tentu saja tidak dapat dipahami bahwa Allah menyatu dengan diri manusia, sebagaimana dipahami

${ }^{63}$ Seperti 'Abd ar-Rahman bin Nashir bin as-Sa'di, dengan karyanya Taysì al-Karim al-Rahmān fì Tafsìi Kalami al-Manān dan Syekh Muhammad bin Shaleh al-'Utsaimin, dengan karyanya Syarh al-'Aqidah al-Wäsithiyyah. ${ }^{64}$ M. Quraish Shihab, Tafsìr al-Mishbäh Vol. I, (Jakarta: Lentera Hati, 2012), cet. V, 492.

${ }^{65}$ Lihat surah al-A'raf [7]: 172, ar-Rūm [30]: 30. Rasul mengatakan : Setiap anak yang lahir berdasar atas fitrah, maka kedua orang tuanya yang menyebabkan anak itu Yahudi, Nasrani atau Majusi.

${ }^{66}$ Fitrah beragama manusia itu akan muncul kepermukaan manakala ditimpa musibah atau kesulitan lainnya, ia memhon atau berdo'a kepada Allah untuk kebaikan dirinya. tetapi setelah kesulitan itu berlalu menjadi lupalagi, seolah-olah tidak pernah memohon kepada Allah. Lihat ar-Rum [30]: 33. 
oleh sementara kaum sufi. Sebab jika Allah itu menyatu dengan makhluk atau hamba-Nya, hal ini jelas bertentangan dengan prinsi-prinsip tauhid yang diajarkan oleh kitab suci Alquran. Selanjutnya dalam memahami makna kebersamaan, bagi Quraish Shihab, kata (كَ) bersama, tidak selalu berarti bercampur dan menyatunya satu hal atau lebih dengan hal yang lain dua atau lebih dalam satu kesatuan. Firman-Nya (وَهُوَ مَعْكُمْ (Allah), Dia bersama kamu, jika ia ditujukan kepada makhluk secara umum, kebersamaan itu adalah pengetahuan-Nya, dan bila ditujukan kepada orang-orang mukmin, kebersamaannya adalah batuan dan dukungannya.

Pemahaman Quraish Shihab seperti diuraikan pada aya-ayat terdahulu merupakan sikpnya yang sangat hati-hati dalam menjelaskan ungkapan atau kalimat yang secara harfiahnya bisa terjebak kepada paham tasybih dan tajsim. Sikap yang sama juga telah dilakukan oleh ulama terdahulu dengan menghindari berbagai hal penyerupaan (tasybib) terhadap Allah dengan makhluk baik dalam sifat maupun perbuatan dengan prinsip (tidak ada sesuatu pun yang semisal (sama) dengan Allah).

Berkenaan dengan media atau sarana yang bisa mengantarkan seorang hamba dekat atau bersama dengan Allah terdapat beberapa isyarat ayat-ayat Alquran yang menyebut sifat-sifat terpuji, seperti takwa, ihsan, sabar, iman, qurbah (qarib, taqarrub) adalah hal-hal pokok memiliki cakupan makna yang sangat luas, sehingga bila diaplikasikan dalam aktfitas sehari-hari akan melahirkan kebaikan-kebaikan yang bernilai ibadah yang disukai Allah, sedangkan ibadah dalam Islam meliputi ibadah mabdhah dan ibadah gairu mabdhah. Dengan mewujudkan sifatsifat tersebut akan mengantarkan seseorang dekat dengan Allah dan bersama Allah, Insya Allah.

\section{Penutup}

Allah menyipati diri-Nya Maha Dekat dengan makhluk atau hamba, serta Allah dapat bersama dengan makhluk atau hamba-Nya adalah merupakan kenyataan dan pernyataan Allah sendiri yang secara tersurat terdapat dalam Alquran seperti surah al-Baqarah [2] 186, Hūd [11] 61, Qāf [50] 16, al-Waqi'ah [56] 16, Saba' [34] 50. Sedangkan ayat-ayat yang terkaait kebersamaan, seperti al-Baqarah [2] 153, , 194, an-Nisā [4] 108, al-Anfāl [8] 19, 46, 66, atTaubah[9] 36,123, an-Nahl [16] 128, al-'Ankabūt [29] 69, al-Hadīd [57] 4.

Kedekatan Allah dengan makhluk atau hamba-Nya adalah kedekatan rahmat-Nya bagi hamba-hamba-Nya, Maha Dekat dengan pengetahuan dan pertolongan, Kami (Allah) bersama malaikat-malaikat — dengan pengetahuan Kami itu—lebih dekat kepadanya daripada urat lehernya, betapa Allah Maha Mengetahui keadaan manusia yang paling tersembunyi sekalipun, dekat janji pertolongan dan dukungan kepada yang taat.

Setelah dipahami dan dicermati, terdapat ayat-ayat yang menyatakan kedekatan dan kebersamaan-Nya dengan makhluk atau hamba disebutkan secara umum untuk semua makhluk atau hamba-Nya, tetapi ada pula ayat yang menyebutkan kedekatan dan kebersamaan Allah itu dengan mengaitkan sifat-sifat atau karakter terpuji yang dimiliki hamba-Nya, seperti takwa, ihsan, sabar, iman, qurbah (qarib, taqarrub), yaitu merupakan sifat-sifat yang disukai Allah.

Ayat-ayat yang menyebut dekat itu merupakan kenyataan dalam Alquran yang tentu saja tidak dapat dipahami bahwa Allah menyatu dengan diri manusia, sebagaimana dipahami oleh sementara kaum sufi. Sebab jika Allah itu menyatu dengan makhluk atau hamba-Nya, hal ini jelas bertentangan dengan prinsi-prinsip tauhid yang diajarkan oleh Alquran "tidak ada yang serupa dengan Allah".

Dalam memahami makna kebersamaan, bagi Quraish Shihab, kata (مَ) bersama, tidak selalu berarti bercampur dan menyatunya satu hal atau lebih dengan hal yang lain dua atau lebih dalam satu kesatuan. Firman-Nya (وَهُوَ مَعَكُمْ (وَ), Dia (Allah) bersama kamu, jika ia ditujukan kepada makhluk secara umum, kebersamaan itu adalah pengetahuan-Nya, dan bila ditujukan kepada orang-orang mukmin, kebersamaannya adalah bantuan dan dukungannya.

${ }^{67}$ Syekh al-Gunaiman, Syarh al-'Aqidqh al-Wāsthyyah, 7/15, dalam Maktabah Syamilah. 
Selanjutnya terdapat beberapa indikasi (petunjuk ayat) yang bisa mengantarkan seorang hamba dekat atau bersama dengan Allah dengan isyarat ayat-ayat Alquran yang menyebut sifat-sifat terpuji, seperti takwa, ihsan, sabar, iman, qurbab (qarib, taqarrub) adalah hal-hal pokok memiliki cakupan makna yang sangat luas sehingga bila diaplikasikan dalam aktifitas seharihari akan melahirkan kebaikan-kebaikan yang bernilai ibadah di sisi Allah.

\section{Daftar Pustaka}

Alquran Digital.

'Abd ar-Rahman bin Nashir bin as-Sa'di, (2000). Taysir al-Karim al-Rahmān fi Tafsìi Kalami alManān, Muassasah ar-Risalah, Madinah al-Munawwarah.

Ahmad Warson Munawwir, (1997). al-Munawwir Kamus Arab Indonesia, Pusaka Progressif, Surabaya.

Ahmad, (2004). Pengajian Tasawuf Sir di Kalimantan Selatan, Antasari Press, Banjarmasin.

Abu al-Fida Ismail Ibn Katsir, (2009). Tafsìr Alqurān al-'Ažbìm, Dār al-Fikri, Beirut.

Badr ad-Din Muhammad ibn Abd Allah az-Zarkasyi, (1975). Al-Burban fi Ulum Alquran, Dar al-Ihya al-Kutub al-Misriyyah, Mesir.

Hasan Zaini, (1997). Tafsir Tematik. Ayat-Ayat Kalam Tafsir al-Maraghi, Pedoman Ilmu Jaya, Jakarta.

Ibrahim Anis dkk, al-Mu'jam al-Wasith, Majma' al-Lugah al-'Arabiyyah, tt.

Muchoyyar, (2002). Pengantar, dalam Nor Ichwan, Memabami Babasa Al-Qur'an, Pustaka Pelajar, Semarang.

Muhammad Husain az-Zahabi, (1976). At-Tafsir wa al-Mufassirun, Dār al-Fikri, Kairo.

Muhammad Sayyid Thanthawi, At-Tafsìr al-Wasith, I/3957 dalam Maktabah Syämilah.

Muhammad Khalil Harras, Syarah al-'Aqidah al-Wäsithiyyah, dalam Maktabah Syamilah.

M. Quraish Shihab, (1995). Membumikan Alquran, Mizan, Bandung, cet. ke-11, Maktabah Syämilah.

Nasruddin Baidan, (2002). Metode Penafsiran Alquran Kajian KritisTerhadap Ayat-Ayat yang Beredaksi Mirip, Pustaka Pelajar,Yogyakarta.

Syekh Muhammad bin Shaleh al-'Utsaimin, Syarh al-'Aqìdah al-Wäsithiyyah 2/91, dalam Maktabah Syamilah.

Tim Penyusun Kamus Pusat Pembinaan dan Pengembangan Bahasa, (1990). Kamus Besar Bahasa Indonesia, Balai Pustaka, Jakarta, cet. ke-3.

Tim Penejemah Kementerian Agama, (1977). Alquran dan Terjemahnya, Bumi Restu, Jakarta. http://kasminarif.blogspot.co.id, diakses tanggal 20 November 2017.

http://kompasiana.com diakses 13 November 2017.

http://kasminarif.blogspot.co.id, diakses tanggal 21 Mei 2017. 